\title{
PENGARUH KEPEMIMPINAN DAN LINGKUNGAN KERJA TERHADAP SEMANGAT KERJA ASN DI SEKRETARIAT DAERAH KABUPATEN MAJENE
}

\author{
The Influence of Leadership and Work Environment on the Morale of ASN in the Regional Secretariat \\ of Majene Regency
}

\author{
Zool Ilham ${ }^{1}$, Andi Rasyid Pananrangi ${ }^{2}$, Syamsul Bahri ${ }^{2}$ \\ ${ }^{1}$ Sekretariat Daerah Kabupaten Majene, Sulawesi Barat \\ ${ }^{2}$ Program Studi Ilmu Administrasi Negara, Program Pascasarjana, Universitas Bosowa \\ Email: zoolilham20@gmail.com
}

Diterima: 14 Agustus 2020

Dipublikasikan: 07 Desember 2020

\begin{abstract}
ABSTRAK
Penelitian ini bertujuan untuk: Mengetahui dan menganalisis pengaruh kepemimpinan dan lingkungan kerja terhadap semangat kerja ASN di Sekretariat Daerah Kabupaten Majene dan mengetahui variabel dominan yang mempengaruhinya. Penelitian ini dilakukan dengan menggunakan pendekatan survei dan menyebar kuesioner untuk menganalisis fakta dan data-data yang menunjang keterangan yang diperlukan untuk mendukung pembahasan penelitian. Sedangkan jenis penelitian adalah deskriptif kuantitatif yaitu menguraikan dan menjelaskan tentang pengaruh kepemimpinan dan lingkungan kerja terhadap semangat kerja ASN di Sekretariat Daerah Kabupaten Majene. Hasil penelitian menunjukkan bahwa: Kepemimpinan berpengaruh positif dan signifikan terhadap semangat kerja ASN di Sekretariat Daerah Kabupaten Majene; Lingkungan kerja berpengaruh positif dan signifikan terhadap semangat kerja ASN di Sekretariat Daerah Kabupaten Majene, artinya lingkungan kerja semakin baik dan kondusif, maka semangat kerja ASN juga akan meningkat. Dari kedua variabel tersebut, variabel kepemimpinan memiliki pengaruh yang dominan terhadap semangat kerja ASN di Sekretariat Daerah Kabupaten Majene, karena memiliki nilai beta yang lebih besar dibandingkan dengan variabel lainnya.
\end{abstract}

Kata Kunci : Kepemimpinan, Lingkungan Kerja, Semangat Kerja, Majene

\begin{abstract}
This study aims to: Know and analyze the influence of leadership and work environment on the morale of ASN at the Regional Secretariat of Majene Regency and to determine the dominant variables that influence it. This research was conducted using a survey approach and distributing questionnaires to analyze facts and data that support the information needed to support the research discussion. While the type of research is quantitative descriptive, which describes and explains the influence of leadership and work environment on the morale of ASN at the Regional Secretariat of Majene Regency. The results showed that: Leadership has a positive and significant effect on the morale of ASN in the Regional Secretariat of Majene Regency; The work environment has a positive and significant effect on the morale of ASN at the Regional Secretariat of Majene Regency, meaning that the work environment is getting better and conducive, so the morale of ASN will also increase. Of the two variables, the leadership variable has a dominant influence on the morale of ASN at the Regional Secretariat of Majene Regency, because it has a beta value that is greater than the other variables.
\end{abstract}

Keywords: Leadership, Work Environment, Morale, Majene

\section{PENDAHULUAN}

Undang-Undang Nomor 23 tahun 2014 tentang pemerintahan daerah membawa perubahan yang signifikan terhadap pembentukan perangkat daerah, dengan prinsip tepat fungsi dan tepat ukuran daerah. Hal ini juga sejalan dengan prinsip penataan organisasi perangkat daerah yang rasional, proposional, efektif dan efisien.

Sumber daya manusia merupakan aset yang paling penting yang harus dimiliki oleh organisasi dan sangat diperhatikan oleh pengelola organisasi tersebut. Istilah sumber daya manusia yang merujuk kepada orang- orang yang ada dalam organisasi. Pada saat pengelola terlibat dalam aktivitas-aktivitas sumber daya manusia sebagai bagian dari pekerjaannya, mereka berupaya manfasilitasi kontribusi yang diajukan oleh orang-orang yang mencapai rencana-rencana dan strategi- strategi organisasi. Artinya penting upaya- upaya sumber daya manusia adalah bermuara dari kenyataan bahwa orang-orang atau manusia merupakan elemen yang selalu ada dalam setiap organisasi (Simamora, 2004).

Pengertian sumberdaya manusia yang dikemukakan oleh Hasibuan (2014) yaitu Kemampuan terpadu dan daya pikir dengan fisik yang dimiliki seseorang sangat menentukan kecepatan dan ketepatan kualitas hasil pekerjaan, sehingga bila semua jenis dan sumber tingkat pekerja dipadukan dengan baik akan mendapatkan irama kerja yang dinamis dan produktif. Berdasarkan pengertian tersebut, maka dapat diartikan bahwa sumber daya manusia merupakan salah satu sumber daya yang terdapat dalam organisasi meliputi semua orang yang melakukan aktifitas. Sumber daya manusia adalah tempat menyimpan daya, karena manusia memiliki akal, perasaan, keinginan, 
dorongan, kemampuan, keterampilan, pengetahuan, dan karya. Sumber daya manusia merupakan potensi yang memiliki rasio, rasa dan karsa. Potensi tersebut sangat berpengaruh dalam pencapaian tujuan organisasi. Lingkungan Kerja, Motivasi dan Kompetensi, parsial maupun simultan berpengaruh signifikan terhadap Kinerja pegawai pada Badan Kesbangpol Provinsi Sulawesi Selatan (Ishak et. al , 2021).

Dalam rangka pembinaan penyelenggaraan pemerintahan daerah, pemerintah mempersiapkan pemberian penghargaan (award) kepada daerah yang mempunyai prestasi kinerja tertinggi secara nasional sesuai ketentuan PP 35 Tahun 2010 tentang Pelaksanaan UU No. 20 Tahun 2009 tentang Gelar Tanda Jasa dan Tanda Penghormatan. Selanjutnya untuk pembenahan yang fundamental serta sikap konsisten terhadap sistem penyelenggaraan pemerintahan yang berorientasi pada pelayanan terbaik kepada masyarakat dengan kinerja yang lebih efisien maka semua peraturan perundang-undangan perlu diimplementasikan secara nyata. Oleh karena itu, harus ada komitmen yang kuat bagi pemerintah daerah sehubungan dengan tugas manajerialnya untuk menyelenggarakan otonomi daerah yang lebih demokratis, efektif dan efisien di masa- masa yang akan datang. Pemerintah daerah Kabupaten Majene juga harus mampu memenuhi kebutuhan tenaga aparatur pemerintah daerah yang lebih berkualitas dan profesional serta memiliki etika dan moral yang baik.

Sejalan dengan hal tersebut dalam menyikapi agenda reformasi pemerintahan secara menyeluruh, salah satu unsur pelaksana Pemerintah Daerah Kabupaten Majene adalah Sekretariat Daerah Kabupaten Majene dituntut agar lebih efektif, efisien dan profesional dalam setiap pekerjaan yang dihadapi. Aktivitas kerja dan berbagai program kerja di Sekretariat Daerah Kabupaten Majene yang menuntut kualifikasi sumber daya manusia aparatur agar mampu berbuat secara terarah, kreatif dan inofatif dalam meningkatkan semangat kerja.

Keberhasilan suatu organisasi sangat dipengaruhi oleh semangat kerja pegawainya. Semangat kerja merupakan salah satu faktor yang sangat penting untuk mendapatkan hasil kerja yang optimal. Ketika seorang merasakan ia mempunyai semangat kerja tentunya ia akan berusaha semaksimal mungkin dengan segenap kemampuan yang dimilikinya untuk menjalankan tugasnya dengan baik, dan ia akan mempunyai tanggung jawab terhadap pekerjaannya sehingga segala tugas yang diberikan tentunya akan dapat dilaksanakan dengan hasil kerja yang baik pula. Semangat kerja ini akan mempengaruhi tingkat absensi, keluhan-keluhan, atau bahkan perputaran tenaga kerja, ataupun masalah-masalah vital organisasi yang lain.

Nitisemito (2017) berpendapat bahwa semangat kerja adalah melakukan pekerjaan secaralebih giat sehingga dengan demikian pekerjaan akan diharapkan lebih cepat dan lebih baik. Selanjutnya Moekijat (2016) menambahkan bahwa: Semangat kerja adalah kemampuan sekelompok orang untuk bekerja sama dengan giat dan konsekuen dalam mengejar tujuan bersama. Jadi, semangat kerja adalah sikap mental individu atau kelompok yang terdapat dalam suatu organisasi yang menunjukkan rasa kegairahan di dalam melaksanakan tugas-tugas atau pekerjaan dan mendorong mereka untuk bekerja secara lebih baik dan lebih produktif. Selanjutnya Mangkunegoro (2016) menyatakan bahwa: Tinggi rendahnya semangat kerja dalam suatu organisasi dipengaruhi oleh beberapa aspek, antara lain: hubungan kerja yang harmonis, kepuasan para pekerja, adanya rasa kemanfaatan bagi tercapainya tujuan organisasi, dan adanya perlindungan dari segala sesuatu yang membahayakan pegawai. Oleh karena itu, kelima aspek tersebut menjadi indikator penelitian karena diyakini mampu membentuk variabel semangat kerja ASN di Sekretariat Daerah Kabupaten Majene.

Sehubungan dengan semangat kerja ASN di Sekretariat Daerah Kabupaten Majene masih tergolong rendah. Hal ini dapat diketahui melalui tingkat absensi pegawai pada tahun 2018, yang menunjukkan pegawai yang alpa atau tanpa keterangan tidak masuk kerja sebanyak 21 orang, 31 orang sakit, dan 14 orang izin (Sekda Kab. Majene, 2018). Hal ini berarti tingkat absensi pegawai tersebut mengindikasikan semangat kerja pegawai masih rendah yang diakibatkan oleh masih adanya subyektivitas dalam pemerintahan, kepemimpinan belum efektif, belum adanya sanksi/ hukuman disiplin yang diterapkan, serta kedisiplinan pegawai masih rendah. Selain itu, lingkungan kerja juga kurang mendukung termasuk fasilitas kerja masih kurang memadai sehingga pegawai tidak dapat melaksanakan tugas dengan baik. Sehubungan dengan beberapa fenomena di atas, dapat dijelaskan semangat kerja ASN di Sekretariat Daerah Kabupaten Majene sangat ditentukan oleh kepemimpinan dan lingkungan kerja yang baik. Oleh karena itu, faktor-faktor yang diyakini mempengaruhi kinerja pegawai di Sekretariat Daerah Kabupaten Majene, antara lain: kepemimpinan dan lingkungan kerja.

Menurut Robbins (2017), kepemimpinan adalah kemampuan untuk mempengaruhi kelompok menuju pencapaian tujuan organisasi. Kepemimpinan yang efektif sangat penting untuk membentuk dan meningkatkan kinerja individu, kelompok maupun organisasi. Beberapa hal yang perlu diperhatikan untuk dapat memimpin dengan baik, antara lain: pengawasan pimpinan, inspirasional pimpinan, kharismatik pimpinan, dan rangsangan intelektual pimpinan. Hal ini menunjukkan kepemimpinan merupakan faktor penentu keberhasilan pelaksanaan tugas pokok pegawai secara efektif dalam mengkoordinir dan mewujudkan mekanisme kerja yang baik. Kepemimpinan di Sekretariat Daerah Kabupaten Majene dapat dilihat dari adanya koordinasi atasan terhadap bawahan yang akan membantu pegawai dalam menyelesaikan pekerjaan dengan baik. Oleh karena itu, variabel kepemimpinan perlu dikaji agar dapat diketahui pengaruhnya terhadap semangat kerja ASN pada Sekretariat Daerah Kabupaten Majene. Adapun tujuan penelitian adalah untuk mengetahui kepemimpinan 
berpengaruh signifikan terhadap semangat kerja ASN di Sekretariat Daerah Kabupaten Majene, mengetahui lingkungan kerja berpengaruh signifikan terhadap semangat kerja ASN di Sekretariat Daerah Kabupaten Majene, dan mengetahui variabel manakah yang dominan pengaruhnya terhadap semangat kerja ASN di Sekretariat Daerah Kabupaten Majene.

\section{METODE}

\section{Pendekatan Penelitian}

Penelitian ini dilakukan dengan menggunakan pendekatan survei dan menyebar kuesioner untuk menganalisis fakta dan data-data yang menunjang keterangan yang diperlukan untuk mendukung pembahasan penelitian. Sedangkan jenis penelitian adalah deskriptif kuantitatif yaitu menguraikan dan menjelaskan tentang pengaruh kepemimpinan dan lingkungan kerja terhadap semangat kerja ASN di Sekretariat Daerah Kabupaten Majene.

\section{Jenis dan Sumber Data}

1. Data kuantitatif, yaitu data yang diperoleh dan disajikan dalam bentuk angka-angka atau laporan yang terdiri dari jumlah pengawai, masa kerja, tingkat pendidikan.

2. Data kualitatif, yaitu data yang berupa informasi atau keterangan keterangan yang diperoleh dari pengawai yang disajikan dalam bentuk non angka.

Data yang diperlukan dalam penelitian ini bersumber dari:

1. Data primer yaitu data yang diperoleh dengan menggunakan daftar pertanyaan yang telah terstruktur dengan tujuan untuk mengumpulkan informasi dari responden pada lokasi penelitian.

2. Data sekunder, data yang diperoleh dari bahanbahan literatur seperti dokumen-dokumen, hasilhasil penelitian terdahulu, jurnal, artikel, laporanlaporan dan kepustakaan lainnya yang dapat mendukung dalam penyelesaian penelitian ini.

Teknik Pengumpulan Data

1. Observasi yaitu peneliti mengadakan pendekatan kepada beberapa bahagian tertentu seperti: bagian administrasi, personalia dan lain-lain untuk memperoleh data yang berkaitan dengan penelitian ini.

2. Dokumentasi yaitu peneliti mencatat dari arsip-arsip atau dokumen yang diberikan terkait dengan penelitian ini.

3. Kuesioner (questioner) yaitu melakukan pengumpulan data melalui pembagian daftar pertanyaan kepada responden

Populasi dan Sampel

Populasi dalam penelitian ini adalah seluruh pegawai di Kantor Sekretariat Daerah Kabupaten Majene yang berjumlah 96 orang. sampel dalam penelitian ini menggunakan metode sampling jenuh dimana seluruh populasi dijadikan sampel yang 96 unit sampel sebagai responden.

\section{Metode Analisis Data}

1. Analisis deskriptif, yaitu digunakan untuk menguraikan secara deskriptif karakteristik responden dan variabel- variabel penelitian melalui distribusi frekuensi, rata-rata dan persentase.

2. Analisis kualitatif dengan menggunakan model regresi linear berganda, yaitu digunakan untuk menganalisis pengaruh variabel kepemimpinan dan lingkungan kerja terhadap semangat kerja ASN di Sekretariat Daerah Kabupaten Majene. Adapun rumus yang digunakan (Sugiyono dan Wibowo, 2002:251), adalah

$$
\begin{aligned}
& \mathrm{Y}=\mathrm{b} 0+\mathrm{b} 1 \mathrm{X} 1+\mathrm{b} 2 \mathrm{X} 2+\mathrm{e} \ldots \ldots \ldots \ldots \ldots \ldots \ldots \ldots \\
& \text { dimana: } \\
& \mathrm{Y}=\text { Semangat kerja ASN } \\
& \mathrm{X} 1=\text { Kepemimpinan } \mathrm{X} 2 \quad=\text { Lingkungan } \\
& \mathrm{b} 0=\text { Intercept/konstanta } \mathrm{b} 1-\mathrm{b} 3=\text { Koefisien regresi } \\
& \mathrm{e} \quad=\text { Standar error }
\end{aligned}
$$

\section{HASIL DAN PEMBAHASAN}

Sebelum melakukan analisis regresi berganda, terlebih dahulu melakukan uji normalitas. Uji normalitas dilakukan untuk melihat apakah model regresi yang digunakan memiliki residual yang terdistribusi secara normal. Suatu regresi apabila didapatkan residual yang tidak tersebar secara normal maka akan menghasilkan regresi yang tidak baik atau tidak konsisten dan efisien.

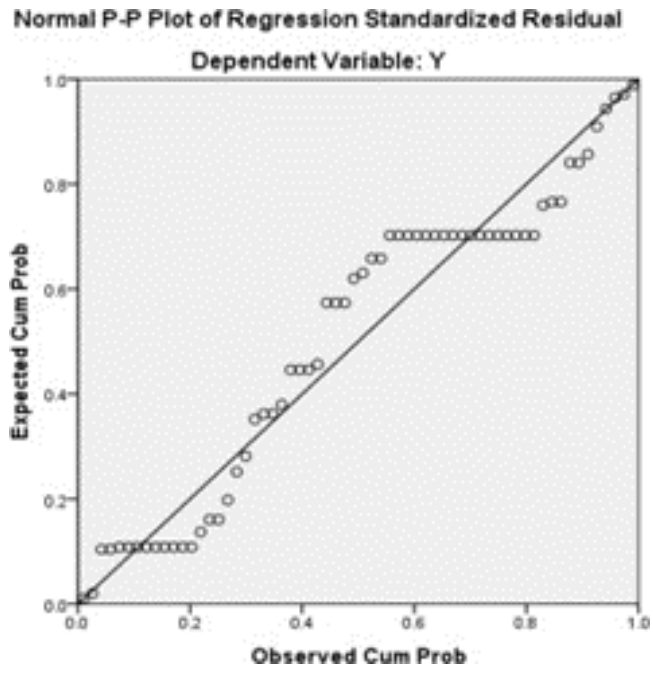

Gambar 1 Hasil Uji Normalitas

Berdasarkan Gambar 1 dapat dijelaskan bahwa sebaran titik berada sepanjang garis diagonal, yang berarti model regresi yang digunakan dalam penelitian ini telah memenuhi asumsi kenormalan dari data sehingga diharapkan hasilnya akan baik atau akan sesuai dengan asumsi klasik dari suatu regresi.

Uji multikolinearitas dilakukan untuk melihat adanya korelasi yang erat antara variabel bebas yang akan digunakan dalam suatu regresi. Keberadaan multikolinearitas dalam suatu regresi akan mengganggu 
hasil regresi tersebut sehingga tidak menghasilkan parameter yang efisien dan efektif atau akan membuat kesalahan dalam parameter yang dihasilkan. Regresi yang baik adalah suatu regresi yang tidak memiliki multikolinearitas di dalamnya sehingga tidak ada gangguan yang diharapkan akan terjadi pada regresi tersebut.

Uji multikolinearitas dapat dilakukan dengan menggunakan program SPSS. Keberadaan multikolinearitas suatu regresi dapat dilihat melalui nilai VIF (Variance Inflation Factors) atau nilai toleransinya. Keberadaan multikolinearitas tersebut dapat diketahui apabila nilai VIF > 10 atau dengan melihat nilai toleransinya $<0,1$.

Adapun hasil uji multikolinearitas pada regresi yang digunakan dalam penelitian ini, dapat dilihat pada Tabel 1 .

Tabel 1 Hasil Uji Multikolinearitas

\begin{tabular}{lcc}
\hline \multirow{2}{*}{ Model } & \multicolumn{2}{c}{ Collinearity Statistics } \\
\cline { 2 - 3 } & Tolerance & VIF \\
\hline (Constant) & 0,573 & 1,745 \\
Kepemimpinan Lingkungan Kerja & 0,573 & 1,745 \\
\hline Sumber: Analisa Data 2020
\end{tabular}
Sumber: Analisa Data 2020.

Berdasarkan data pada Tabel 10 dapat dijelaskan bahwa semua variabel memiliki nilai VIF $<10$ dan nilai toleransinya $>0,1$. Ini menunjukkan bahwa keberadaan multikolinearitas pada persamaan yang dilakukan tidak terbukti. Dengan kata lain, tidak terdapat multikolinearitas dalam persamaan yang dilakukan atau hubungan yang terjadi antar variabel bebas dalam hal ini kepemimpinan, dan lingkungan kerja dapat ditoleransi sehingga tidak akan mengganggu hasil regresi.

Salah satu uji yang sangat penting dilakukan adalah keberadaan varians dari data tersebut atau disebut uji heterokedastisitas. Pengujian ini dilakukan untuk melihat apakah pengambilan sampel dilakukan dengan benar pada populasi yang tepat atau dengan perkataan lain apakah terjadi ketidaksamaan varians dari residual regresi tersebut. Suatu model regresi yang mengandung heterokedastisitas akan menghasilkan parameter yang bias sehingga akan menyebabkan kesalahan dalam perlakuannya. Suatu model regresi dikatakan baik apabila di dalamnya tidak diperoleh heterokedastisitas melainkan homokedastisitas.

Melalui program SPSS, uji heterokedastisitas dapat dilihat dengan melihat plot grafik atau hubungan antara variabel terikat dengan nilai residualnya. Heterokedastisitas akan muncul apabila terdapat pola tertentu antar keduanya seperti pola bergelombang dan kontinyu atau menyempit atau melebar teratur. Homokedastisitas akan muncul apabila tidak diperoleh pola yang jelas atau titik-titik yang diperoleh menyebar di atas dan di bawah angka 0 pada sumbu Y.

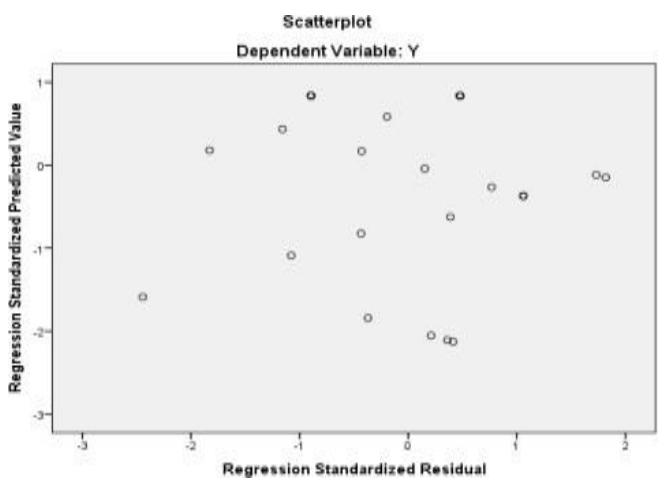

Gambar 2 Hasil Uji Heteroskedastisitas

Berdasarkan Gambar 3 dapat dijelaskan titik-titik menyebar di antara titik nol dan berada menyebar di atas dan di bawah garis nol tersebut secara acak. Ini dapat dikatakan bahwa model regresi tersebut tidak menunjukkan adanya heterokedastisitas melainkan adanya homokedastisitas sehingga tidak menghasilkan parameter yang bias yang akan menyebabkan kesalahan dalam perlakuannya.

Untuk menguji hipotesis yang digunakan dalam penelitian ini, yakni untuk pengujian hipotesis pertama digunakan uji $\mathrm{F}$ dan pengujian hipotesis kedua digunakan uji t. Uji-F digunakan untuk mengetahui pengaruh secara simultan atau bersama-sama faktor independen (bebas) terhadap faktor dependen (terikat). Sedangkan uji-t digunakan untuk mengetahui pengaruh secara parsial atau individu faktor independen (bebas) terhadap faktor dependen (terikat).

Hasil pengujian secara simultan atau serempak menunjukkan bahwa variabel kepemimpinan, dan lingkungan kerja secara bersama-sama berpengaruh positif dan signifikan terhadap semangat kerja ASN pada Sekretariat Daerah di Kabupaten Majene.

Tabel 2 Hasil Pengujian secara Simultan

\begin{tabular}{cccccc}
\multicolumn{7}{c}{ ANOVAb } \\
\hline Sum of & Mean & & \\
Model & Squares & df & Square & F & Sig. \\
\cline { 1 - 4 } Regression & 18.219 & 2 & 9.110 & 176.262 & $.000 \mathrm{~b}$ \\
Residual & 4.80 & 93 & .052 & & \\
\cline { 1 - 4 } Total & 23.025 & 95 & & & \\
\hline
\end{tabular}

a.Predictors: (Constant), X2, X2 1

b.Dependent Variable: Y

Sumber: Analisa Data 2020.

Hasil uji ANOVA (Analysis of Variant) atau uji $\mathrm{F}$ dalam penelitian diperoleh nilai F-hitung 176.262 > nilai F- tabel 3,44 $(\mathrm{dfl}=2 ; \mathrm{df} 2=93 ; \alpha 0,05)$ atau nilai probabilitasnya $0,000<$ nilai $\alpha 0,05$. Dengan demikian, dapat disimpulkan bahwa variabel kepemimpinan dan lingkungan kerja secara simultan berpengaruh positif dan signifikan terhadap semangat kerja ASN pada Sekretariat Daerah Kabupaten Majene. Selanjutnya besarnya pengaruh secara simultan dari variabel kepemimpinan, dan lingkungan kerja terhadap semangat kerja ASN pada Sekretariat Daerah Kabupaten Majene dapat diketahui melalui koefisien determinasi (R2). 
Tabel 3 Hasil Pengujian Deterinansi

\begin{tabular}{ccccc}
\multicolumn{5}{c}{ Model Summaryb } \\
\hline Model & $\mathrm{R}$ & $\mathrm{R}$ & $\begin{array}{c}\text { Adjusted R } \\
\text { Square }\end{array}$ & $\begin{array}{c}\text { Std. Error of the } \\
\text { Square }\end{array}$ \\
\hline & $.890^{\mathrm{a}}$ & .791 & .787 & .22734 \\
\hline
\end{tabular}

a.Predictors: (Constant), X3, X2, X1

b.Dependent Variable: Y

Sumber: Analisa Data 2020.

Besarnya koefisien determinasi (R2) adalah 0,791. Angka koefisien determinasi ini menyatakan bahwa secara simultan variabel kepemimpinan dan lingkungan kerja pada Sekretariat Daerah Kabupaten Majene memberikan kontribusi dalam peningkatan semangat kerja ASN sebesar 79,1 persen, sedangkan sisanya sebesar 20,9 persen dipengaruhi oleh variabel lain yang tidak dimasukkan dalam penelitian ini

Pengujian secara parsial digunakan untuk melihat pengaruh antara variabel variabel kepemimpinan, dan lingkungan kerja secara parsial (individu) terhadap semangat kerja ASN di Sekretariat Daerah Kabupaten Majene. Hasil pengujian secara parsial dapat dilihat dari nilai t-hitungnya.

Tabel 4 Hasil Pengujian secara Parsial (Uji-t)

\begin{tabular}{cccccc}
\hline \multirow{2}{*}{ Model } & \multicolumn{2}{c}{$\begin{array}{c}\text { Unstandardized } \\
\text { Coefficients }\end{array}$} & $\begin{array}{c}\text { Standardized } \\
\text { Coefficients }\end{array}$ & \multirow{2}{*}{$\mathrm{t}$} & \multirow{2}{*}{ Sig. } \\
\cline { 2 - 5 } & $\mathrm{B}$ & Std. Error & Beta & & \\
\hline Constant) & .763 & .223 & & 3.422 & .001 \\
\hline $\mathrm{X} 1$ & .524 & .050 & .652 & 10.413 & .000 \\
$\mathrm{X} 2$ & .314 & .062 & .315 & 5.027 & .000 \\
\hline
\end{tabular}

a.Dependent Variable: Y

Sumber: Analisa Data 2020.

Nilai t-hitung dan signifikansi/probabilitas dari variabel bebas tersebut, yakni: variabel kepemimpinan dengan nilai t-hitung 10,413 dan sig. 0,000, dan variabel lingkungan kerja dengan nilai t- hitung 5,027 dan sig. 0,000. Sedangkan t- tabel pada df2 (95) dan tingkat kesalahan $\alpha 0,05$ diperoleh t-tabel adalah sebesar 1,98. Hal ini berarti t-hitung dari variabel bebas tersebut lebih besar dari t-tabel atau nilai signifikansi/probabilitasnya lebih kecil dari a 0,05, yakni: untuk variabel kepemimpinan dengan nilai t-hitung 10,413 > 1,98 atau nilai signifikansi $0,000<0,05$ (berpengaruh signifikan); dan variabel lingkungan kerja dengan nilai t-hitung 5.027 $>1,98$ atau nilai signifikansi $0,000<0,05$ (berpengaruh signifikan). Dengan demikian, dapat disimpulkan bahwa variabel kepemimpinan, dan lingkungan kerja berpengaruh positif dan signifikan terhadap semangat kerja ASN di Sekretariat Daerah Kabupaten Majene

\section{KESIMPULAN DAN SARAN}

Kesimpulan hasil penelitian ini bahwa kepemimpinan berpengaruh positif dan signifikan terhadap semangat kerja ASN pada Sekretariat Daerah Kabupaten Majene. Artinya semakin efektif kepemimpinan, maka semangat kerja ASN akan semakin meningkat pula. Lingkungan kerja berpengaruh positif dan signifikan terhadap semangat kerja ASN pada Sekretariat Daerah Kabupaten Majene. Artinya semakin baik dan kondusif lingkungan kerja, maka semangat kerja ASN juga akan semakin meningkat pula. Kepemimpinan berpengaruh dominan terhadap semangat kerja ASN pada Sekretariat Daerah Kabupaten Majene, karena memiliki nilai beta yang lebih besar dibandingkan variabel lainnya.

\section{DAFTAR PUSTAKA}

Hasibuan, Malayu S. P., 2014. Manajemen Sumber Daya Manusia. Edisi Revisi. Rineka Cipta, Jakarta.

Ishak, A. W. A., Pananrangi, A. R., \& Nurkaidah, N. (2021). Pengaruh Lingkungan Kerja, Motivasi Dan Kompetensi Terhadap Kinerja Pegawai Pada Lingkup Badan Kesatuan Bangsa Dan Politik Provinsi Sulawesi Selatan. Jurnal Paradigma Administrasi Negara, 2(2), 62-66.

Mangkunegara, 2017. Manajemen Sumber Daya Manusia Perusahaan, PT Remaja Rosdakarya, Bandung.

Moekijat, 2012. Manajemen Kepegawaian, Cetakan KeVII, Penerbit Mandar Maju, Bandung.

Nitiseminoto, Alex. S., 2017. Manajemen Personalia (Manajemen Sumber Daya Manusia). Edisi Revisi. Ghalia Indonesia, Jakarta.

Robbins, Stephen, P., 2017. Perilaku Organisasi: Konsep, Kontroversial, dan Aplikasi, PT Prenhallindo, Terjemahan, Jakarta.

Simamora, H., 2014. Manajemen Sumber Daya Manusia. Edisi 2. Bagian Penerbitan STIE YKPN, Yogyakarta.

Sugiyono, 2014. Statistika untuk Penelitian, Cetakan keempat, Penerbit Alfabeta, Bandung.

Undang-Undang Nomor 23 tahun 2014 tentang Pemerintahan Daerah 